\title{
PELAKSANAAN PENGUJIAN ROKET AIR PADA PESANTREN KREATIF YATIM MANDIRI KABUPATEN JEMBER
}

\author{
Intan Hardiatama ${ }^{1}$, Indra Nurtjahjaningtyas ${ }^{1}$, Muhammad Trifiananto ${ }^{1}$ \\ ${ }^{1}$ Fakultas Teknik, Universitas Jember \\ Email: intan.hardiatama@unej.ac.id
}

\begin{abstract}
Abstrak
Perguruan Tinggi hendaknya melaksanakan fungsi Tiga Dharma Perguruan Tinggi, yaitu fungsi belajar/mengajar, penelitian dan pengabdian masyarakat secara terpadu. Pelaksanaan pengabdian masyarakat oleh dosen-dosen dari suatu perguruan tinggi memiliki peran strategis, karena adanya transfer iptek yang diperlukan masyarakat, dengan prioritas yang berlatar belakang ekonomi dan pendidikan rendah. Yatim Mandiri merupakan sebuah Lembaga Amil Zakat Nasional (LAZNAS) milik masyarakat Indonesia yang memiliki misi mengangkat harkat sosial kemanusiaan yatim dhuafa dengan dana ZISWAF (Zakat, Infaq, Shadaqah, Wakaf) serta pendanaan lainnya yang halal dan legal dari perusahaan / lembaga perorangan, kelompok, (http://yatimmandiri.org/page/kilas-sejarah.html). Yayasan Yatim Mandiri Kabupaten Jember pada bulan Ramadhan 1439 H mengadakan "Pesantren Ramadhan Kreatif"dengan peserta anakanak yatim dari berbagai wilayah di Kabupaten Jember. UNEJ bekerjasama dengan Yatim mandiri untuk terselenggaranya pelatihan roket air dngan konsep fun learning ini. Pada acara ini juga sekaligus dilaksanakan pengabdian berupa pengenalan konsep roket air dan penerapannya. Tujuan dari pengabdian ini antara lain dapat meningkatkan kemandirian anak yatim, meningkatkan pengetahuan tentang sains beserta aplikasinya, meningkatkan antusiasme siswa untuk belajar sains, dan meningkatkan motivasi ibadah di bulan suci ramadhan dengan kegiatan positif. Metode quisioner digunakan untuk mengavaluasi hasil kegiatan ini. Kegiatan yang dilakukan berupa praktek pembuatan, pengujian, pemberian materi, dan Tanya jawab roket air. Dari hasil quisioner pelatihan ini menarik bagi seluruh peserta. Serta antusiasme peserta untuk belajar roket dan ilmu sains lebih lanjut sangat tinggi. Hasil dari kegiatan ini, para peserta kegiatan lebih memahami prinsip kerja roket air dan launchernya.
\end{abstract}

Kata kunci: Pengabdian, roket air, yatim mandiri

\section{PENDAHULUAN}

Perguruan Tinggi hendaknya melaksanakan fungsi Tigadarma atau Tridharma
Perguruan Tinggi, yaitu fungsi belajar/ mengajar, penelitian dan pengabdian kepada masyarakat secara terpadu. Dharma ketiga, yaitu Pengabdian kepada 
DIFUSI

Volume 3, No.2 Juli 2020

Masyarakat sebagai salah satu dari ketiga dharma atau kewajiban tersebut harus dilaksanakan tepat sasaran, agar Perguruan Tinggi tersebut tidak menjadi menara gading di tengah masyarakat. Pelaksanaan Pengabdian Masyarakat oleh dosen-dosen dari suatu perguruan tinggi memiliki peran strategis, karena adanya transfer iptek yang diperlukan masyarakat, dengan prioritas yang berlatar belakang ekonomi dan pendidikan rendah.

Kabupaten Jember mempunyai luasan wilayah $3.293,34 \mathrm{~km}^{2}$, dengan garis pantai sepanjang $170 \mathrm{~km}$. Luas perairan Kabupaten Jember yang termasuk Zona Ekonomi Ekslusif (ZEE) $\pm 8.338,5 \mathrm{~km}^{2}$. Jumlah penduduk miskin jember berkisar 243 ribu jiwa 9,98\% dari jumlah penduduk tahun 2018 (BPS Kabupaten Jember) [1].

Program Pengabdian Mayarakat merupakan usaha menurunkan tingkat kemiskinan di Indonesia yang sudah dimulai awal tahun 1970-an. Upaya tersebut mengalami tahapan saturasi pada tahun 1980-an namun hasilnya kurang optimal, sehingga jumlah orang miskin pada awal 1990-an kembali meningkat. Islam memiliki konsep untuk menciptakan keseimbangan sosial dalam wujud ekonomi, lebih tepatnya kesejahteraan masyarakat, sebagai upaya membantu program-program pengentasan kemiskinan di Indonesia. Ajaran Islam tentang zakat dan wakaf, menerapkan kedua potensi besar tersebut untuk mengurangi angka kemiskinan yang bersifat kompleks dan struktural. Potensi penerimaan wakaf di Indonesia sangatlah besar, hal ini disebabkan penduduk mayoritas Indonesia beragama Islam. Keberadaan wakaf bisa menjadi sesuatu yang bisa diandalkan dalam menopang perekonomian umat Masalah pengelolaan wakaf, menjadi suatu masalah yang sangat urgen dan sangat rentan karena masyarakat kabupaten Jember mayoritas beragama Islam [2]. Yatim Mandiri adalah sebuah Lembaga Amil Zakat Nasional (LAZNAS) milik masyarakat Indonesia yang berkhidmat mengangkat harkat sosial kemanusiaan yatim dhuafa dengan dana ZISWAF (Zakat, Infaq, Shadaqah, Wakaf) serta dana lainnya yang halal dan legal, dari perorangan, kelompok, perusahaan, atau lembaga [3].

Yayasan Yatim Mandiri Kabupaten Jember dalam bulan Ramadlan 1439 H ini mengadakan "Pesantren Ramadhan Kreatif" dengan peserta anak-anak yatim dari berbagai wilayah di Kabupaten Jember. Islam pernah mengalami masa keemasan yang dikenal dengan istilah dengan The Golden Age, yaitu masa dimana umat Islam telah mencapai puncak kejayaan dalam bidang ekonomi, peradaban dan sains. Ilmuwan-ilmuwan besar dari berbagai ilmu pengetahuan banyak dilahirkan pada masa itu, akan tetapi tidak banyak generasi penerus yang mengenal ilmuwan muslim tersebut.

Ilmu pengetahuan umumnya dapat dipelajari dengan membaca atau bereksperimen langsung. Namun menurut Iswandi [4] tingkat literasi sains di indonesai tergolong rendah yaitu peringkat 62 dari 69 negara yang diteliti. Hail penelitian ini tentunya bukan kabar yang menggembirakan untuk dunia pendidikan. Oleh karena itu diperlukan inovasi untuk meningkatkan minat belajar siswa melalui inovasi metode belajar yang 
DIFUSI

Volume 3, No.2 Juli 2020

menarik. Widiyatmoko [5] melakukan penelitian tentang konsep fun learning, hasilnya menunjukan bahwa konsep fun learning memberikan hasil yang lebih baik dibandingkan pembelajaran formal. Lestariningrum [6] menerapkan metode ekperimen untuk mengetahui seberapa besar peningkatan kognitif anak pada bidang sains dasar, hasilnya metode eksperimen mampu meningkatkan kemampuan kognitif anak didik. Konsep fun meningkatkan pemetaan kemampuan peserta didik mencapai tahap adaptasi, sedangkan pada pembelajaran formal hanya mencapai pada tahu dan melakukan saja.

Berdasarkan analisis situasi kondisi yang ada, maka dapat diambil perumusan masalah yaitu: "Bagaimana caranya dapat berperan serta mengajarkan konsep-konsep ilmu pengetahuan dan penerapannya kepada anak-anak yatim yang tergabung dalam Pesantren Ramadhan Kreatif yang diselenggarakan oleh Yayasan Yatim Mandiri Kabupaten Jember?"

Roket air adalah salah satu jenis roket yang menggunakan air sebagai bahan pendorong [7]. Wahana tekan yang berfungsi sebagai mesin roket biasanya terbuat dari botol plastik bekas minuman ringan kapasitas 1,5 Liter. Air dipaksa keluar oleh udara yang terkompresi dengan tekanan tinggi dari kompresor atau pompa tangan. Konstruksi roket air ditampilkan pada Gambar 1.

Prinsip kerja roket air dapat dijelaskan sebagai berikut:

1) Udara tekan ditambahkan kedalam botol yang menciptakan sebuah gelembung yang mengambang diatas air dan kemudian menekan volume udara di bagian atas botol.

2) Botol dilepaskan dari pompa setelah tekanan dirasa sudah tinggi.

3) Air mendorong keluar nossel oleh udara yang telah terkompresi.

4) Botol terdorong menjauh dari air karena mengikuti hukum Newton Ketiga
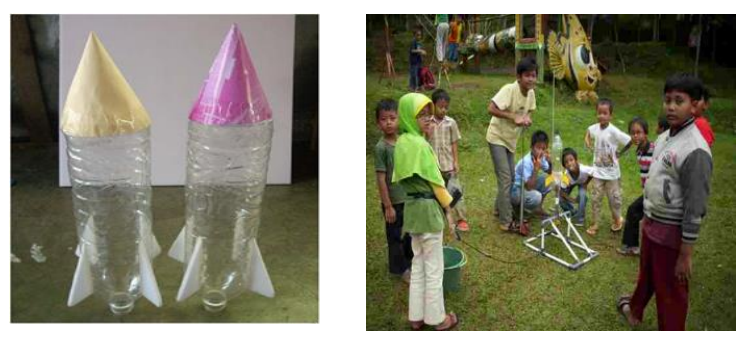

Gambar 1. Roket air dan Launchernya (Sumber: Divisi Water Rocket FT UNEJ)

Tujuan pengabdian masyarakat ini antara lain meningkatkan kemandirian anak yatim, meningkatkan pengetahuan tentang sains beserta aplikasinya, meningkatkan motivasi ibadah di bulan suci ramadhan dan sebagai salah satu program solusi keyatiman. Pemecahan masalah yang akan diambil yakni melalui pelatihan pembuatan dan pengujian roket air dan launchernya.

\section{METODE}

Program pengabdian masyarakat ini berlokasi di taman wisata rembangan Jember pada hari minggu 24 Juni 2018. Sasaran pengabdian ini adalah yayasan yatim mandiri Kabupaten Jember yang diwakili oleh siswa berjumlah 32 Orang siswa kelas 2 dan 3 SD. Metode yang dilakukan berupa pelatihan pembuatan 
DIFUSI

Volume 3, No.2 Juli 2020

roket air dan launcher serta pengujian roket air dan launcher. Praktek pembuatan roket dan launcher dibuat sederhana dan mudah dipahami. Penggunaan bahan - bahan diupayakan berasal dari bahan yang mudah didapat di lingkungan misalnya barang bekas. Bahan dan alat untuk pembuatan roket air ditunjukkan seperti gambar 2 di bawah ini. Setelah proses pembuatan peluncur roket air selesai, maka peserta didik diajak untuk ikut serta dalam pengujian alat. Uji coba peluncuran roket bermanfaat agar siswa yatim mandiri lebih memahami prinsip kerja roket air dan launchernya. Untuk mengetahui respon dan manfaat kegiatan pengabdian ini untuk peserta, sebelum acara berakhir diberikan lembar quisioner. Bahan pembuatan peluncur roket dijelaskan pada Tabel 1.

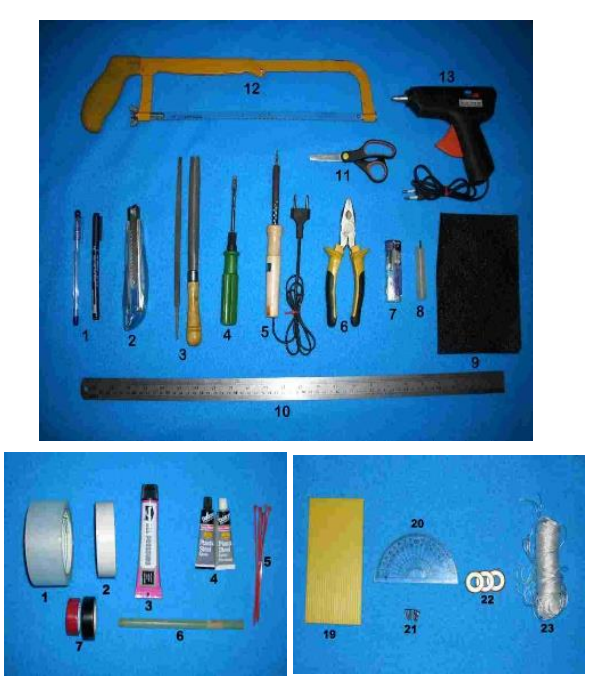

Gambar 2. Peralatan Untuk Pembuatan Roket Air dan Launcher

Tabel 1. Bahan yang digunakan untuk pembuatan rocket

\begin{tabular}{|c|c|c|}
\hline No. & Uraian & Satuan \\
\hline 1 & Hose Quick Connector & 1 Buah \\
\hline 2. & Soket PVC ukuran 1/2" & 2 buah \\
\hline 3. & Soket drat PVC ukuran $1 / 2 "$ & 2 buah \\
\hline 4. & Tosen klep PVC (katup satu arah) ukuran 1/2" & 1 buah \\
\hline 5. & Knee PVC ukuran $1 / 2$ " & 6 buah \\
\hline 6. & Tee PVC ukuran 1/2" & 8 buah \\
\hline 7. & Pipa PVC ukuran $1 \frac{1}{2}{ }^{\prime \prime}$ & $\begin{array}{l}\text { PVC abu-abu: } 30 \mathrm{~cm} \text { PVC putih: } \\
\pm 4 \mathrm{~m}\end{array}$ \\
\hline 8. & Dop PVC ukuran 1/2" & 3 buah \\
\hline 9. & Plastik dari bekas minuman soda & Secukupnya \\
\hline 10. & Klem ukuran 11/4" (klem no. 16) & 2 \\
\hline 11. & Klem ukuran 11⁄2" (klem no. 12) & 1 \\
\hline 12. & Bunglon atau pentil bekas sepeda motor & 1 \\
\hline 13. & Ban dalam bekas & Secukupnya \\
\hline 14. & Aluminium solid/pipa aluminium & $\begin{array}{l}\text { Panjang } 1,5 \mathrm{~m}, \\
\text { diameter } 0,9 \mathrm{~cm}\end{array}$ \\
\hline 15. & Impraboard warna kuning & Secukupnya \\
\hline 16. & Busur derajat & 1 buah \\
\hline 17. & Sekrup kecil panjang ukuran $1 / 2$ “" & 1 buah \\
\hline 18 & Pemberat (ring Besi) & 2 Buah \\
\hline 19 & Benang Nylon & Secukupnya \\
\hline 20 & Baut Kecil & 1 Buah \\
\hline
\end{tabular}


DIFUSI

Volume 3, No.2 Juli 2020

\section{HASIL DAN PEMBAHASAN}

Output dari pengabdian kepada masyarakat ini berupa Alat Peluncur Roket Air (Launcher). Prinsip kerja dari launcher adalah sebagai penghasil tekanan yang diperoleh dari pompa tangan untuk mendorong air (fluida incompressible) yang menempati ruang di dalam badan roket. Tekanan yang mampu dicapai untuk mendorong roket air ini dapat mencapai $\mathrm{P}=5$ bar.

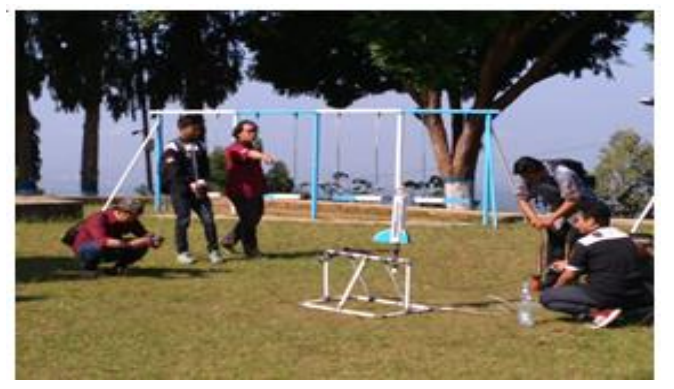

Gambar 4. Uji Coba Peluncur Roket Air

Tipe Tunggal oleh Mahasiswa Tim Water Roket, Teknik Mesin FT UNEJ

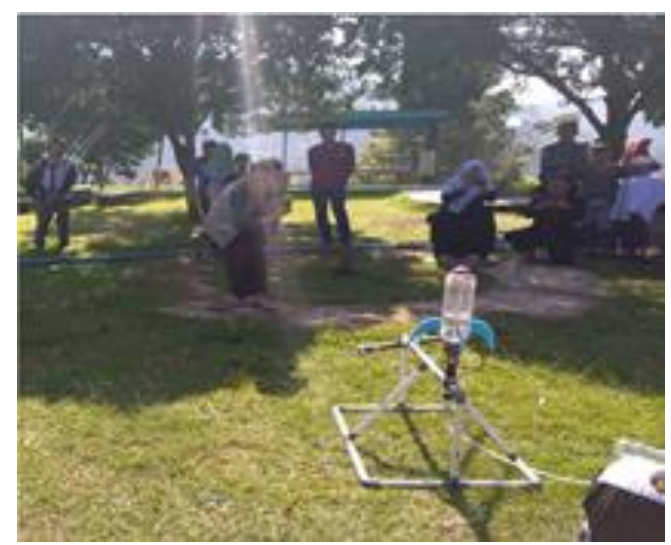

Gambar 5. Uji Coba Peluncur Roket Air Arah Vertikal

Gambar 4 dan 5 menampilkan uji coba peluncur roket air yang disaksikan langsung oleh siswa-siswi yatim-piatu Insan Kreatif Kabupaten Jember. Peluncuran dilaksanakan di Hotel Rembangan, Ka- wasan Wisata Rembangan Jember. Demonstrasi peluncuran roket air dilakukan dengan mengambil arah vertikal dan melambung (membentuk berbagai sudut).

Praktek peluncuran roket air dilakukan dalam suasana kegembiraan, dimana Tim Pengabdian masyarakat dibantu oleh mahasiswa komunitas pecinta roket air memberikan penjelasan dan praktek langsung di depan anak-anak yatim piatu peserta pelatihan. Para siswa-siswi menyaksikan dan dapat praktik langsung di lapangan. Para siswa diberi kesempatan untuk bertanya dan diskusi langsung di lapangan.

Siswa-siswi yatim piatu insan kreatif juga dikenalkan dalam membuat kreatifitas model peluncur roket air. Model peluncur roket air yang dikenalkan dalam pelatihan ini adalah pelncur roket air sistem ganda, akan tetapi karena keterbatasan waktu, maka siswa-siswi hanya ditunjukkan model peluncur yang dimiliki Tim Water Roket Mahasiswa Teknik Mesin FT-UNEJ seperti ditampilkan dalam Gambar 6.

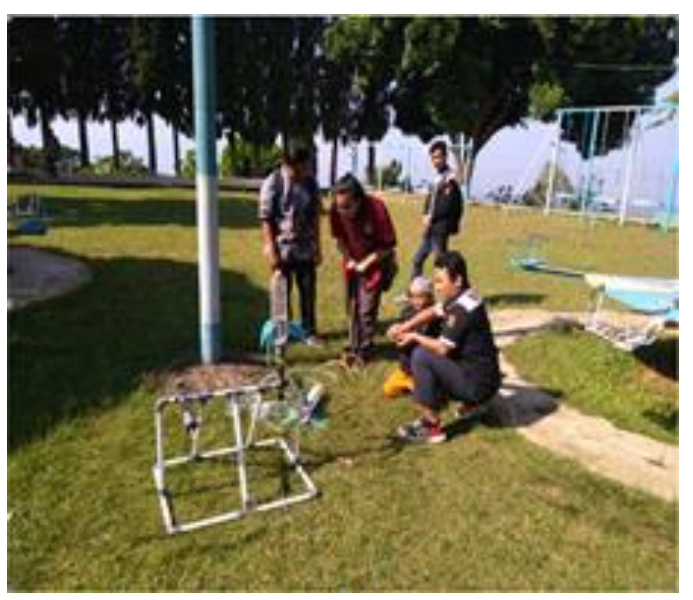

Gambar 6. Pengenalan Peluncur Roket Sistem Ganda. 
DIFUSI

Volume 3, No.2 Juli 2020

Tabel 2. Hasil Quisioner

\begin{tabular}{llcc}
\hline No & Pertanyaan & \multicolumn{2}{c}{ Jawaban (\%) } \\
& Ya & Tidak \\
\hline 1 & Kegiatan belajar roket air ini sangat & 100 & 0 \\
& menarik & 78,125 & 21,875 \\
2 & Pembuatan roket air mudah & 90,625 & 9,375 \\
3 & Tanya jawab / diskusi mudah dipahami & 6,25 \\
4 & Kegiatan ini membuat saya tertarik & 93,75 & \\
& belajar ilmu sains & 93,75 & 6,25 \\
5 & Saya ingin membuat roket & 87,5 & 12,5 \\
6 & Saya ingin belajar roket air lebih lanjut \\
\hline
\end{tabular}

Pengenalan peluncur model ganda ini perlu disampaikan karena dalam berbagai kompetisi roket air, sering dijumpai permasalahan yang bersifat non teknis. Hambatan yang sering dijumpai di lapangan yang paling sering adalah kebocoran pada nozzle. Kebocoran pada nozzle menyebabkan kehilangan tekanan pada badan roket, sehingga jarak elevasi dan jarak jelajah yang dapat ditempuh roket menjadi berkurang. Kebocoran yang parah pada nozzle menyebabkan roket tidak dapat meluncur sama sekali.

Peluncur roket air biasanya dapat dipasang langsung busur derajat untuk mengukur sudut peluncuran yang akan dilakukan. Pengukuran sudut peluncuran dilakukan secara manual. Perkembangan teknologi digital memungkinkan kontrol peluncuran dilakukan dengan menggunakan remote control. Aneka ragam kreatifitas pembuatan peluncur roket air juga diberikan secara sekilas melalui presentasi saja, hal ini disebabkan keterbatasan waktu dan biaya.

Antusiasme siswa selama mengikuti pelatihan sangat positif, hal ini ditunjukkan dengan banyaknya pertanyaan yang muncul dari siswa selama mengikuti pe- latihan. Pelatihan dilakukan di alam terbuka memberikan hasil yang sangat efisien, karena pelatihan disampaikan secara praktis, sehingga siswa dapat memahami konsep fundamental fisika tanpa melalui kajian teoritis yang rumit. Pelatihan pembuatan peluncur roket ini menitikberatkan pada pengenalan konsep fisika melalui teknik "melihat pertama kali selanjutnya yakin bisa mencoba". Teknik pelatihan ini merupakan salah satu upaya yang dihadapi bangsa Indonesia, bahwa pola anak-anak sudah diracuni bahwa kata "fisika" dan "matematika" identik dengan rumus-rumus yang rumit. Paradigma pemikiran demikian menyebabkan anak-anak menghindari hal-hal yang berhubungan dengan analisis perhitungan.

Setelah sesi tanya jawab berakhir peserta diberikan quisioner tentang kegiatan yang telah dilakukan. Dari pertanyaan pertama quisioner didapatkan semua siswa menjawab kegiatan belajar roket air yang telah dilakukan menarik . Pembelajaran yang menarik dengan fun learning ini dapat meningkatkan minat siswa dan partisipasi siswa kedalam kegiatan pelatihan dan belajar ini. Selanjutnya meskipun $21,875 \%$ siswa menilai pembuatan roket air tidak mudah namun 
DIFUSI

Volume 3, No.2 Juli 2020

keinginan siswa untuk membuat dan belajar membuat roket air maupun roket lainnya tetap tinggi. $21,875 \%$ siswa yang menganggap pembuatan roket air relatif sulit karena kami menampilkan pembuatan yang terlalu rinci. Ketertarikan dalam mempelajari ilmu sains juga sangat besar, karena metode yang digunakan dalam pelatihan ini turut mengikutsertakan siswa dalam prosesnya. Proses pemberian materi saat peluncuran disertai tanya jawab yang terus mengalir menandakan materi dapat ditangkap dengan baik. Pemberian gambaran tentang masa perkembangan roket juga diharapkan dapat meningkatkan ketertarikan siswa untuk belajar lebih dalam lagi.

Bahan peluncur roket berasal dari material-material yang mudah sekali diperoleh dari toko-toko bangunan terdekat bertujuan untuk merangsang anak agar dapat melakukan dan membuat sendiri sesuai kreatifitas. Hasil pemantauan tim pengabdian masyarakat adalah seluruh peserta pelatihan memerlukan pendampingan dan motivasi untuk belajar, hal ini disebabkan latar belakang peserta didik yang yatim piatu, sehingga memerlukan sandaran pendampingan untuk menggapai cita-citanya.

\section{KESIMPULAN}

Kesimpulan yang diperoleh dari kegiatan pengabdian kepada masyarakat yang diselenggarakan dan dilakukan oleh Tim Pengabdian FT UNEJ sebagai berikut:

a. Tujan dari kegiatan ini tercapai, hal ini terlihat dari data quisioner yang menunjukkan $100 \%$ siswa menja- wab kegiatan pelatihan roket air menarik

b. Proses pembuatan roket air perlu disederhanakan untuk pelatihan selanjutnya pada peserta kelas 2 dan 3 SD.

c. Pelatihan pembuatan peluncur roket air dapat dilakukan dengan baik, yaitu dapat dihasilkan peluncur roket air tipe tunggal

d. Pelatihan pembuatan peluncur roket air perlu dilakukan dengan berbagai model, termasuk model ganda, portable atau sistem kontrol elektronik

e. Sistem pelatihan peluncur roket air di alam terbuka dapat dijadikan sebagai wahana menanamkan rasa percaya diri dan meningkatkan kecintaan siswa kepada bangsa dan negara.

Saran yang dapat disampaikan adalah program pelatihan dengan sistem bermain di alam terbuka perlu dilanjutkan untuk menggugah motifasi anak, Perlu adanya metode pembelajaran yang menarik terutama dalam pembelajaran ilmu-ilmu eksakta, agar anak tidak memiliki sugesti yang keliru perihal ilmu-ilmu pasti

\section{UCAPAN TERIMAKASIH}

Penulis mengucapkan terimakasih kepada Tim Water Roket Mahasiswa Teknik Mesin FT-UNEJ. Terimakasih juga kepada tempat wisata Rembangan Jember yang memfasilitasi lokasi pelaksanaan kegiatan pelatihan ini.

\section{REFERENSI}


[1] B. P. S. (BPS), "Indikator Kemiskinan Kabupaten Jember 2010 - 2018," 2019. [Online]. Available:

https://jemberkab.bps.go.id/dyna mictable/2019/10/24/18/indikato r-kemiskinan-kabupaten-jember2010-2018.html. [Diakses 2 Desember 2019].

[2] S. J. Jatnyana, "Pengelolaan Wakaf Di Jember. Skripsi," Jurusan Manajemen Fakulats Ekonomi Universitas Jember, Jember, 2014.

[3] Anonim, "Kilas Sejarah," yatimmandiri.org, 2018. [Online]. Available:

http://yatimmandiri.org/page/kil as-sejarah.html. [Diakses 1 Juni 2019].

[4] H. Iswandi, "Sekelumet dari Hasil PISA 2015 yang Baru Dirilis," 2016. [Online]. Available: http://www.ubaya.ac.id/2014/co ntent/articles_detail/230/Overvie w-of-PISA2015-result-that-
have-just-been-Realesed.html. [Diakses 2019 Desember 2].

[5] A. Widiyatmoko, "Pengembangan perangkat pembela $\neg$ jar $\neg$ an sains Fisika dengan pendekatan Physics Edutaiment berbantuan CD Interaktif," Jurnal Prime Edu, vol. 1, no. 1, pp. 51-59, 2012.

[6] A. Lestariningrum Dan Nuryanti, "Penerapan Metode Eksperimen Untuk Meningkatkan Konsep Dasarsains Pada Anak Didik Kelompok A Tk Pkk Suruhwadang Kecamatan Kademangan Kabupaten Blitarn Pada Setiap Anak Walaupun Usiamereka Sama. Perbedaan Potensi," Educhild, Vol. 5, No. 1, Pp. 4650, 2016.

[7] F. F. Haryani, R. Amaliah, D. Fitrasari Dan S. Viridi, "Konsep Fisika Dalam Gerak Permainan Roket Air," Dalam Seminar Nasional Pendidikan Sains, Surakarta, 2016. 